\title{
Response of Wheat Plants to Seed Pre-Soaking in Hydrogen Peroxide Solution under Salt Stress Conditions
}

\author{
Mona G. Attia, Amal H. Mahmoud and Amira A. El-Araby ${ }^{1}$
}

\begin{abstract}
Under arid and semi-arid condition of limited water resources, salinity is an important environmental constraint, affecting many crop productivity. The objective of this study is being suggested to examine the contribution of $\mathrm{H}_{2} \mathrm{O}_{2}$-presoaked seeds and salinity levels of irrigation water on growth and yield performance of wheat grown in different textured soils. To meet these objectives, the 3-way factorial experiment, comprising of 3 pre-soaking intervals $(0,24$ and 36h), 3 different levels of saline irrigation water (500, 5000 and $8500 \mathrm{mg} \mathrm{NaCl} / \mathrm{L}$ ) was carried out in two different textured soils (sandy and clay soils), whereas wheat seeds were planted in cemented-bituminized plots $(0.75 \times 1.5 \mathrm{~m})$ until the maturity stage. At tillering, random leaf samples were removed and analyzed for $\mathrm{Na}$ and $K$ contents. At the harvest time, plant growth indices, including height and number of spikes/plot and yield components (straw and grain yields) were recorded.
\end{abstract}

The results have shown that plant growth characteristics and yield potentials were significantly suppressed with increasing the salinity stress of irrigation water, but the rate of decline varied considerably among all trails. The more depressive effects of the salinity exposure were clearly manifested on straw yield, being 74.6 and $85.6 \%$ at 5000 and $8500 \mathrm{mg} \mathrm{NaCl} / \mathrm{L}$, respectively. The pretreatment of seeds with $\mathrm{H}_{2} \mathrm{O}_{2}$ induced acclimation on the plants to salinity. It lessened the deleterious effect of salt stress on the growth of wheat especially when seeds were soaked in $\mathrm{H}_{2} \mathrm{O}_{2}$ for $36 \mathrm{~h}$. This treatment caused relative increases in number of spikes /plot, grain yield, straw yield, defined by $44.5,43.7$, and $72.6 \%$, respectively. Progressive results were achieved on all the studied plant criteria, giving better performance of the sand textured soil than the clay type. Superior wheat growth, maximum yield and highest $K$ content were realized on wheat cultivated in sandy soil irrigated with saline water. Pretreatment of seeds with $\mathrm{H}_{2} \mathrm{O}_{2}$ for $24 \mathrm{~h}$ induced acclimation of the plants to salinity. Moreover, seed priming with $\mathrm{H}_{2} \mathrm{O}_{2}$ for $36 \mathrm{~h}$ improved grain yield potentials and leaf $K$ content in plants grown in sandy soil.

Key words: presoaking seeds - hydrogen peroxide wheat - salt stress

\section{INTRODUCTION}

Soil Salinity and irrigation water quality are among of the most important variables affecting plant growth and yield potentials of different plant species and varieties (Mahajan and Tuteja, 2005). the data reported by FAO (2005) showed that $20 \%$ of the cultivated soil around the River Nile, is provided with good irrigation water quality. Besides, $2.1 \%$ of the agricultural dry-land prevailing in the new reclaimed area is dependent on different quality of ground water, as an alternative irrigation source. With subsequent and frequent surface irrigation, progressive accumulation of salts are being developed along the soil profile. Under poor drainage system and shallow water table, salinity problem is originated in medium and tine-textured soils, depending on the rate of water movement and environmental (Bauder and brock, 2001). In salt-affected soils, plant growth and crop productivity are seriously affected, because of the disruption of metabolic path-way and nutrional disorder (Silva, et al., 2008).

Salt stress exhibit different strategies in plants that allow them to overcome stress. It induces damage to plant cells catalyzed by reactive oxygen species (ROS) (Azevedo-Neto et al., 2006). Plants have a complex antioxidative system to prevent the oxidative damage of ROS that involves both non enzymatic and enzymatic antioxidant defenses (Asada, 1999; Azevedo Neto et al., 2006). Hydrogen peroxide $\left(\mathrm{H}_{2} \mathrm{O}_{2}\right)$ in plants is one of the major and the most stable ROS and regulates basic processes, such as acclimation, defense and development (Ślesak et al., 2007).Exogenous $\mathrm{H}_{2} \mathrm{O}_{2}$ can modulate root growth and development of plants under various stress condition and provide more intensive root system in wheat (Hameed et al. 2004).Hydrogen peroxide plays a dual role in plants as the toxic byproduct of normal cell metabolism and as a regulatory molecule in stress perception and signal transduction (Wan and Liu 2008).

Previous reports have shown that seed priming could be used as a beneficial tool to induce quick germination, increasing growth character and yield performance (Gondim et al., 2010). In addition, it promotes the photosynthetic pigments content in the leaves, total carbohydrate percentage, as well as N, P and K contents in wheat grains as compared with untreated -seeds (Amin et al., 2008). Additional data (Gondim et al., 2012) revealed that seed priming with $\mathrm{H}_{2} \mathrm{O}_{2}$ increased the formation of antioxidants in seed, which play an important role in the seedlings emergency to counteract with the oxidative damage and stimulated the seedling

\footnotetext{
${ }^{1}$ Soil Salinity and Alkalinity Research Department; Soils, Water \& Environment Research Institute; Agricultural Research Center (ARC), Alexandria, Egypt.

Received May 29, 2017, Accepted June 29, 2017.
} 
growth under salt-stressed condition. Therefore, seed priming is considered a beneficial tool and is being used to ameliorate the stress tolerance in different crops (Ahmed et al., 2012).

In recent years, the role of $\mathrm{H}_{2} \mathrm{O}_{2}$ in plant acclimation is currently increased from different views. Thus, the aim of this study is being forward to test the contribution of hydrogen peroxide pretreatment of seeds on salt tolerance, yield performance and leaf $\mathrm{Na}$ and $\mathrm{K}$ content of wheat plants grown under salt stress conditions.

\section{MATERIALS AND METHODS}

This investigation was performed to test the effects of seed pretreatment with hydrogen peroxide on salt tolerance of wheat plants. The seeds of wheat variety Giza 168 were obtained from the Crop Research Institute, Agricultural Research Center (ARC) in Giza, Egypt and divided in two parts. The first part of seeds was soaked in $\mathrm{H}_{2} \mathrm{O}_{2}$ solution ( $100 \mathrm{mM}$.) for 24 and $36 \mathrm{~h}$. Later on, the seeds were washed with distilled water and then blot dried. The other part of seeds (non-soaked seeds) was used as the control.

The $\mathrm{H}_{2} \mathrm{O}_{2}$-soaked seeds and non-soaked seeds were sown in cemented- bituminized plots $(0.75 \mathrm{X} 1.5 \mathrm{~m})$ containing 2 different types of soil (sandy and clay) during the growing season 2013/2014. The initial chemical and physical properties of the two types of soil

Table 1. Soil and tap water characteristics

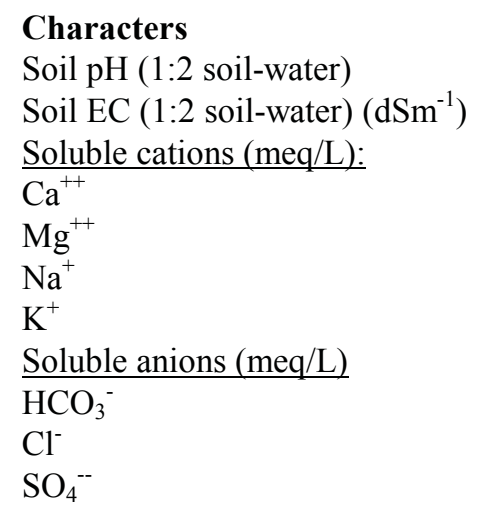

Total $\mathrm{CaCO}_{3}(\%)$

Total nitrogen (\%)

Available phosphorus (mg/kg)

Available potassium $(\mathrm{Cmole} / \mathrm{Kg})$

Organic matter (\%)

Particle size distribution:

Clay

Silt

Sand

Soil texture used and the tap water characteristics are given in table 1 (Page et al., 1982).

A factorial trait, comprising of 3 prepared saline irrigation water levels, i.e., $500\left(\mathrm{~S}_{0}\right), 5000\left(\mathrm{~S}_{1}\right)$ and 8500 $\left(\mathrm{S}_{2}\right) \mathrm{mg} / \mathrm{L}$ using $\mathrm{NaCl}, 3$ soaking period $(0,24,36 \mathrm{~h})$ and 2 types of soil (sandy, clay) were replicated 3 times in a complete randomized design. Plants were subjected to salt stress after sowing. Nitrogen and potassium were applied as ammonium nitrate and potassium sulfate fertilizers, at rates of $100 \mathrm{~kg} \mathrm{~N} / \mathrm{fed}$ and $48 \mathrm{~kg} \mathrm{~K}_{2} \mathrm{O} / \mathrm{fed}$, respectively. The amount of $\mathrm{N}$ fertilizer was partitioned in 3 equal doses for $\mathrm{N}$ (at planting, 3 weeks later and before tillering stage), While $\mathrm{K}$ fertilizer was applied, in one dose, after 6 weeks of planting date. Phosphorus fertilizer was initially incorporated to the soil before cultivation at a rate of $45 \mathrm{~kg} \mathrm{P}_{2} \mathrm{O}_{2} / \mathrm{fed}$.

At maturity (May 2014), the plants were harvested and agronomic data including plant height, grain yield (GY), straw yield (SY) and number of spikes were recorded.

At tillering stage, random leaf sample were removed, washed, oven dried at $70{ }^{\circ} \mathrm{C}$ for $48 \mathrm{hr}$., weighed, and pulverized in stainless steel rotary Knife mill and stored in plastic bags. A portion of $(0.5 \mathrm{~g})$ oven dried leaf samples were completely digested with $5 \mathrm{ml}$ of $\mathrm{H}_{2} \mathrm{SO}_{4}$ conc. and hydrogen peroxide according to Evenhuis and De-Waard (1980).

\begin{tabular}{llll}
\hline Characters & \multicolumn{2}{c}{ Soil } & Tap water \\
Soil pH (1:2 soil-water) & clay & sandy & 7.50 \\
Soil EC (1:2 soil-water) $\left(\mathrm{dSm}^{-1}\right)$ & 7.19 & 7.33 & 0.78 \\
Soluble cations (meq/L): & 1.84 & 1.29 & 3.20 \\
\hline $\mathrm{Ca}^{++}$ & & & 1.75 \\
$\mathrm{Mg}^{++}$ & 6.86 & 3.95 & 2.50 \\
$\mathrm{Na}^{+}$ & 3.70 & 1.42 & 0.35 \\
$\mathrm{~K}^{+}$ & 5.00 & 6.50 & 1.60 \\
$\mathrm{Soluble} \mathrm{anions} \mathrm{(meq/L)}_{\mathrm{HCO}_{3}^{-}}$ & 0.38 & 0.32 & 3.85 \\
$\mathrm{Cl}^{-}$ & & & 2.30 \\
$\mathrm{SO}_{4}^{--}$ & 1.96 & 0.98 & - \\
Total CaCO$_{3}(\%)$ & 2.79 & 2.79 & - \\
Total nitrogen (\%) & 11.19 & 8.42 & - \\
Available phosphorus (mg/kg) & & & - \\
Available potassium $(\mathrm{Cmole} / \mathrm{Kg})$ & 2.55 & 0.85 & - \\
Organic matter (\%) & 0.15 & 0.06 & - \\
Particle size distribution: & 23.12 & 4.75 & - \\
Clay & 1.04 & 0.21 & - \\
Silt & 2.37 & 0.14 & - \\
Sand & & & - \\
Soil texture & 42.9 & 2.00 & \\
\hline
\end{tabular}


The clear digest was quantitatively transferred to $100 \mathrm{ml}$ volumetric flask. In this solution, the concentrations of $\mathrm{Na}^{+}$and $\mathrm{K}^{+}$were measured using flame photometer (JENWAY model PFP7/C).

The term "harvest index, $\mathrm{HI} \%$ " is being introduced to relate the GY to total plant biomass. Accordingly, HI was calculated using the following relation:

$$
\mathrm{HI}(\%)=\{\mathrm{GY} /(\mathrm{GY}+\mathrm{SY})\} \mathrm{X} 100
$$

The obtained data were subjected to the analysis of variance (ANOVA) using CoSTAT ( Co Hort, 1986). The significant differences among treatment means were evaluated on the basis of the calculated values of LSD (Duncan, 1965).

\section{RERSULTS AND DISCUSSION}

The analysis of variance (ANOVA) presented in table 2 revealed that the main variable effects and their interaction imposed significant trend on the most of selected traits at $\mathrm{P} \leq 0.05$. To eliminate the diversion effects of the single and combined treatments on GY and SY performances, the term "harvest index percentage; $\mathrm{HI} \% "$ is being introduced to relate the GY to total plant biomass.

\section{Main treatment effects}

\subsection{Effect of saline irrigation water:}

Irrespective to the effects of soil types and soaking period, the results in table 2 and figure 1 showed that the plants exposed to saline irrigation water imposed marked variations on the all recorded data. Taking the values of plant criteria at the control treatment $\left(\mathrm{S}_{0}, 500\right.$ $\mathrm{mg} \mathrm{NaCl} / \mathrm{L}$ ) as a reference for the relative comparisons, the data revealed that the growth retardation, in terms of plant height, was depressed by 9.2 and $18.9 \%$, when the salinity level of irrigation water was increased to 5000 and $8500 \mathrm{ppm}$, respectively. The inhibitory effects on the number of spikes/ plot were, subsequently declined to 59.51 and $68.7 \%$, at the respective salinity levels. In the contrast, the leaf $\mathrm{Na}$ content (Fig. 1.c) was significantly increased by 19.5 and $30.1 \%$ accompanied by marked drop in leaf $\mathrm{K}$ content, defined by 24.6 and $42 \%$, at $\mathrm{S}_{1}$ and $\mathrm{S}_{2}$, respectively. The calculated depressive effects on yield components at the highest salt level accounted for marked significant decrements, defined by $85.6,74.3 \%$ for straw and grain yields, respectively.

Salinity stress reduces plant growth, alters ionic and osmotic effects and induces oxidative stress (Parida and Das, 2005). Crop performance may be adversely affected by salinity as a result of nutritional disorders.

Table 2. Analysis of Variance (ANOVA) for plant growth indices, grain and straw yield records and leaf chemical composition of wheat plants

\begin{tabular}{|c|c|c|c|c|c|c|c|c|}
\hline \multirow[b]{3}{*}{ SOV } & \multirow[b]{3}{*}{ df } & \multicolumn{7}{|c|}{$\begin{array}{c}\text { Significant } \\
\text { level }\end{array}$} \\
\hline & & \multicolumn{2}{|c|}{$\begin{array}{c}\text { plant growth } \\
\text { indices }\end{array}$} & \multicolumn{3}{|c|}{ Grain \& straw yield records } & \multicolumn{2}{|c|}{$\begin{array}{c}\text { leaf chemical } \\
\text { composition }\end{array}$} \\
\hline & & $\begin{array}{c}\text { Plant } \\
\text { Height } \\
\text { cm }\end{array}$ & $\begin{array}{c}\text { Spikes } \\
\text { No } \\
\text { /plot }\end{array}$ & $\begin{array}{c}\text { Grain } \\
\text { yield } \\
\text { g/plot }\end{array}$ & $\begin{array}{c}\text { Straw } \\
\text { yield } \\
\text { g/plot }\end{array}$ & $\begin{array}{l}\mathrm{HI} \\
\%\end{array}$ & $\begin{array}{c}\mathrm{Na} \\
\%\end{array}$ & $\begin{array}{l}\mathbf{K} \\
\%\end{array}$ \\
\hline Blocks & 2 & ns & ns & ns & ns & ns & ns & ns \\
\hline \multicolumn{9}{|l|}{ Main Effects } \\
\hline soil types & 1 & ** & $*$ & ns & $* *$ & $* *$ & $*$ & $* *$ \\
\hline water salinity & 2 & ** & ** & ** & ** & ** & ** & ** \\
\hline soaking period & 2 & $* *$ & $* *$ & $* *$ & $* *$ & $* *$ & ns & ns \\
\hline \multicolumn{9}{|l|}{ Interaction } \\
\hline soil types $\mathrm{X}$ salinity & 2 & $* *$ & $* *$ & $* *$ & $* *$ & $* *$ & $*$ & $* *$ \\
\hline soil types $\mathrm{X}$ soaking period & 2 & ns & $* *$ & $*$ & $* *$ & ns & $* *$ & $* *$ \\
\hline salinity X soaking period & 4 & ns & $* *$ & $* *$ & $* *$ & $* *$ & $* *$ & $* *$ \\
\hline soil types $\mathrm{X}$ salinity $\mathrm{X}$ soaking period & 4 & ns & ns & ns & $* *$ & $*$ & $* *$ & * \\
\hline Ms Error & 34 & 20.87 & 191.97 & 2801.04 & 4209.6 & 0.004 & 0.035 & 0.033 \\
\hline
\end{tabular}


These disorders may derive from the effect on nutrient availability, competitive uptake, transport or partitioning within the plant (Silva et al., 2008). Besides, the osmotic effect involves limited water absorption due to the salt accumulation in the rhizosphere, exerting intracellular $\mathrm{Na}$ toxicity and nutrient imbalance (Silva et al., 2008).

\subsection{Effect of soil type:}

Regardless to the main effects of salinity level and soaking period, the results outlined on plant growth indices (plant height and spikes No. /plot), harvest index and leaf $\mathrm{k}$ content were progressively increased in the sandy soil as compared with the clay soil (Figure 2).
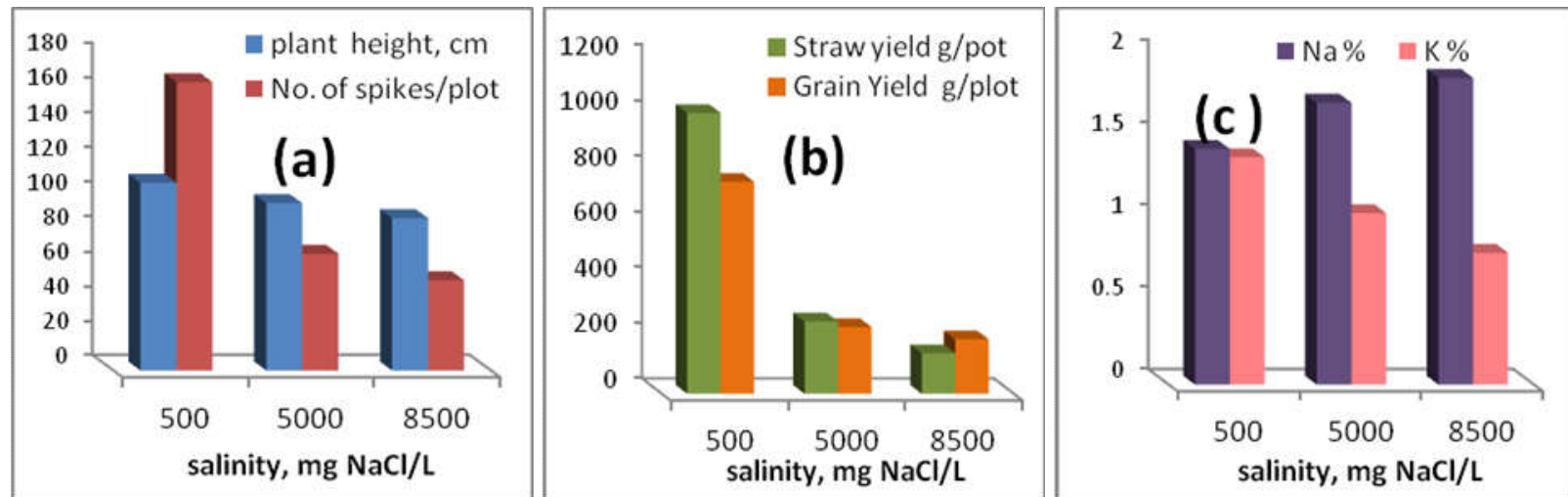

Fig.1. Main effect of salinity on plant growth indices (a), yield components (b) and leaf chemical composition of wheat plants
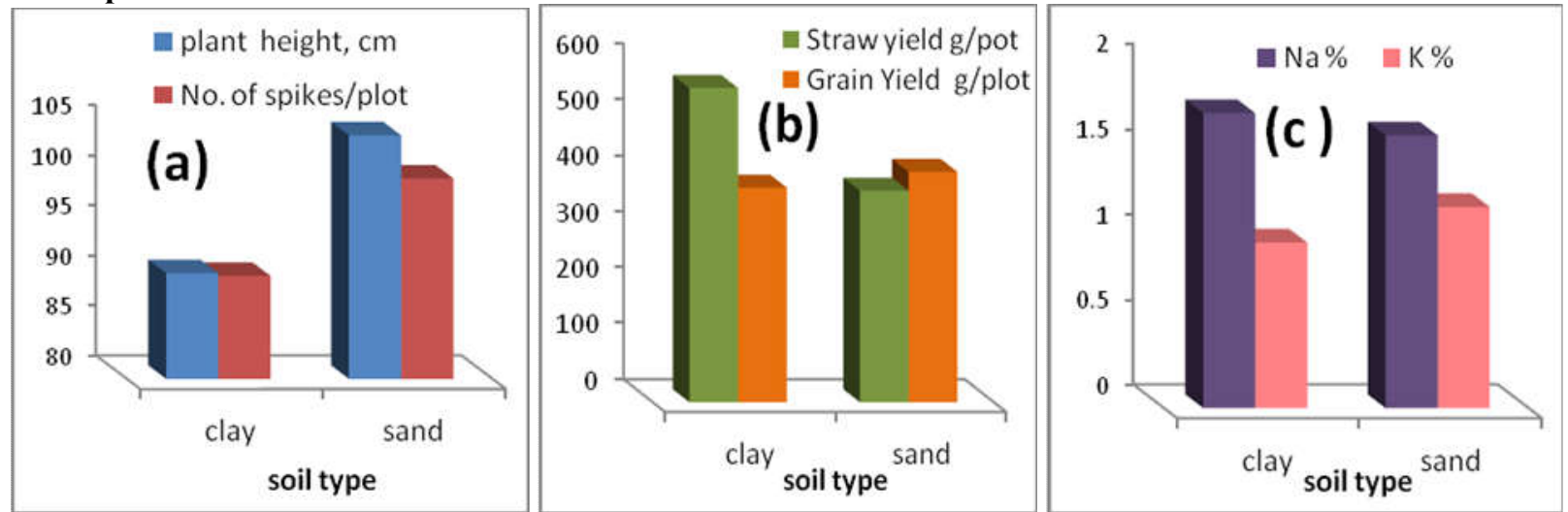

Fig. 2. Main effect of soil type on plant growth indices (a), yield components (b) and leaf chemical composition of wheat plants
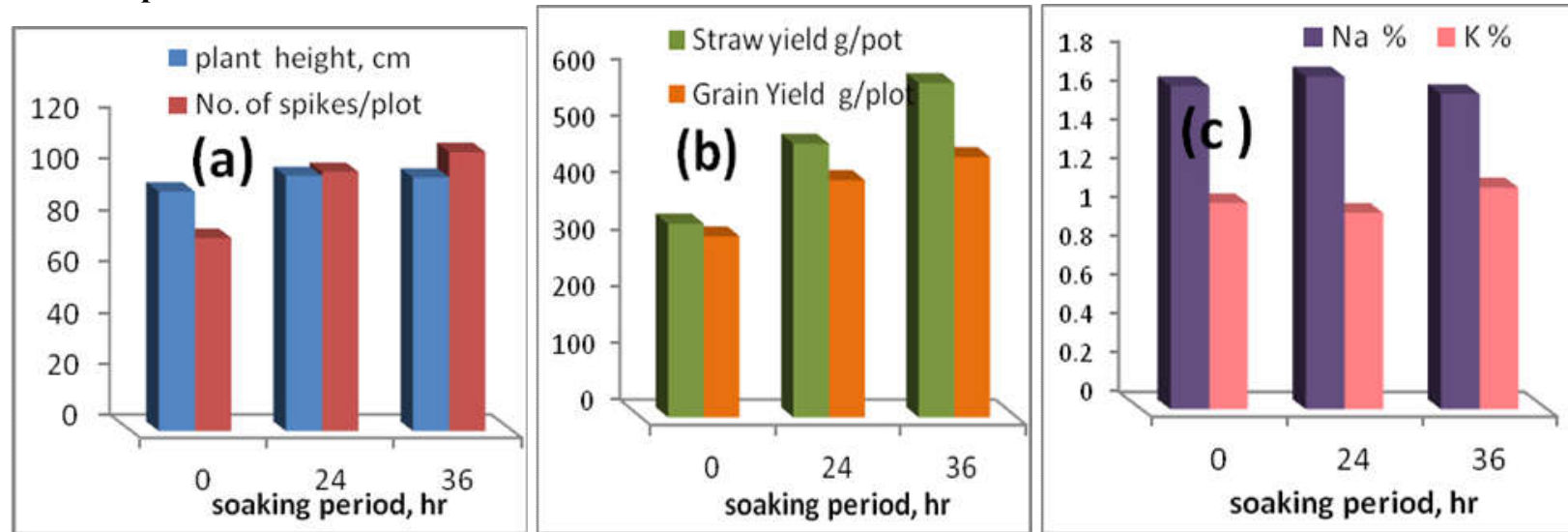

Fig. 3. Main effect of soaking period on plant growth indices (a), yield components (b) and leaf chemical composition of wheat plants 
In contrast, straw yield and leaf $\mathrm{Na}$ content were significantly decreased in sandy soil as compared with the clay soil. The calculated relative increases in plant height, spikes number, grain yield, $\mathrm{HI}$ and leaf $\mathrm{K}$ content in wheat plants grown in the sandy soil as compared to the respective clay soil were defined by $15.2,10.8,7.3$, 20 and $21.6 \%$, respectively, accompanied by extensive drop in straw yield $(32.7 \%)$ and $\mathrm{Na}$ content $(7.5 \%)$.

These results would suggest that the hazarders effect of salt stress, originated from the frequent saline irrigation water on the growing plants was, partially, relevant (apparent) in clay rather than in sandy soils. This fact holds true because of the wide variations between the physical and chemical characteristics of the clay and sandy soils. In other words, the soil moisture retention, associated with short-term of $\mathrm{Na}$ exposure on rooting system and increasing soil porosity are among of the important facts that contributes for better yield performance in sandy soil.

\subsection{Effect of soaking period:}

With respect to the main effects of soaking period intervals on the studied criteria of wheat plants, the data in figure 3 showed that the pre-soaked seeds in $\mathrm{H}_{2} \mathrm{O}_{2}$ up to $36 \mathrm{~h}$ interval significantly increased plant height, number of spikes and $\mathrm{K}^{+}$content. The relative increments were $5.8,44.5$ and $7.5 \%$, respectively, compared with unsoaked seeds. Besides, it induced marked significant increase in grain yield and straw yield defined by 43.9 and $72.6 \%$ respectively, associated with adverable effects in the $\mathrm{HI}$ leaf $\mathrm{Na}^{+}$content, defined by 16.4 and $2.4 \%$, respectively.

The previous studies have shown that the $\mathrm{H}_{2} \mathrm{O}_{2}-$ presoaked seeds of wheat increased antioxidative enzyme activity during germination, suggesting that germination is associated with enhanced cellular capacity to detoxify $\mathrm{H}_{2} \mathrm{O}_{2}$ (Cakmak et al., 1993). Additional data clarified that exogenous $\mathrm{H}_{2} \mathrm{O}_{2}$ treatment simultaneously enhanced multi resistance to heat, chilling, drought and salt stress in maize seedlings (Gong et al., 2001). Uchida et al. (2002) and Azevedo Neto et al. (2005) demonstrated that the pretreatment with $\mathrm{H}_{2} \mathrm{O}_{2}$ in nutrient solution induced acclimation to salt stress in rice and maize seedlings. In maize, Gondium et al. (2010) suggested that soaking seeds in $100 \mathrm{mM} \mathrm{H} \mathrm{H}_{2}$ solution for $36 \mathrm{~h}$ before germination in saline condition led to a salt stress acclimation process and reduced the deleterious effects of salinity on plant growth.

\section{The 2-way interaction:}

\subsection{Salinity - soil type interaction}

The data given in fig. 4 revealed that plant growth index, yield component and leaf chemical composition of wheat plants varied considerably among the two soil types along the salt stress exposure. However, superior growth, maximum yield (SY \& GY), HI \% and the highest $\mathrm{K}$ content in leaf were clearly evident on wheat cultivated in sand soil and irrigated with saline water of 5000 and $8500 \mathrm{mg} \mathrm{NaCl} / \mathrm{L}$. Opposite results were detected in the clay soil as compared with the sandy soil at the control treatments, whereas progressive and remarkable variations in tillering criteria and yield components were clearly manifested in clay soil. The LSD comparisons proved that the differences in all tested criteria between sandy soil and clay soil were significant at $\mathrm{P}=0.05$ (Table 2).

The plants grown under field conditions often endure multiple stresses during their development. However, the vast majority of research has focused on individual stresses in the absence of others. Poor soil physical conditions may contribute for additional stresses in saltaffected areas (Grattan and Oster, 2003). For example, soils with poor structure or impermeable layers could restrict root growth as well as influence water and salt distribution in the soil. Crusting at the soil surface acts as a physical barrier for emerging seedlings and can lead to poor stand establishment particularly if the young seedlings are already weakened by salt stress. Generally, this interaction proved that soil texture is one of the determinal facts that affects the potential of nutrients supply for growth and yield performance under saline conditions (Bauder and Brock 1992 and 2001).

\subsection{Salinity - soaking period interaction}

Except the results detected on plant height criteria, the remaining traits imposed remarkable significant variation when the salinity level were increased, along the soaking period intervals of $\mathrm{H}_{2} \mathrm{O}_{2}$-treated seeds (Table 3 ). The data showed that at any given salinity level, growth vigorous, in term of plant height, was increased with the prolonged intervals of pre-soaked seeds in $\mathrm{H}_{2} \mathrm{O}_{2}$, accompanied with non-significant variation in growth criteria between the soaking period intervals (Table 3).

The results outlined on the number of spikes per plot showed that, only, at the control treatment (non-soaked seeds), the plant response to the increasing intervals of $\mathrm{H}_{2} \mathrm{O}_{2}$ - presoaked seed was clearly pronounced. This trend was, only, noticed, for the plants irrigated with wate of 5000 and $8500 \mathrm{mg} \mathrm{NaCl} / \mathrm{L}$ at $24 \mathrm{~h} \mathrm{H}_{2} \mathrm{O}_{2}$-seed treatment (Table 3). 


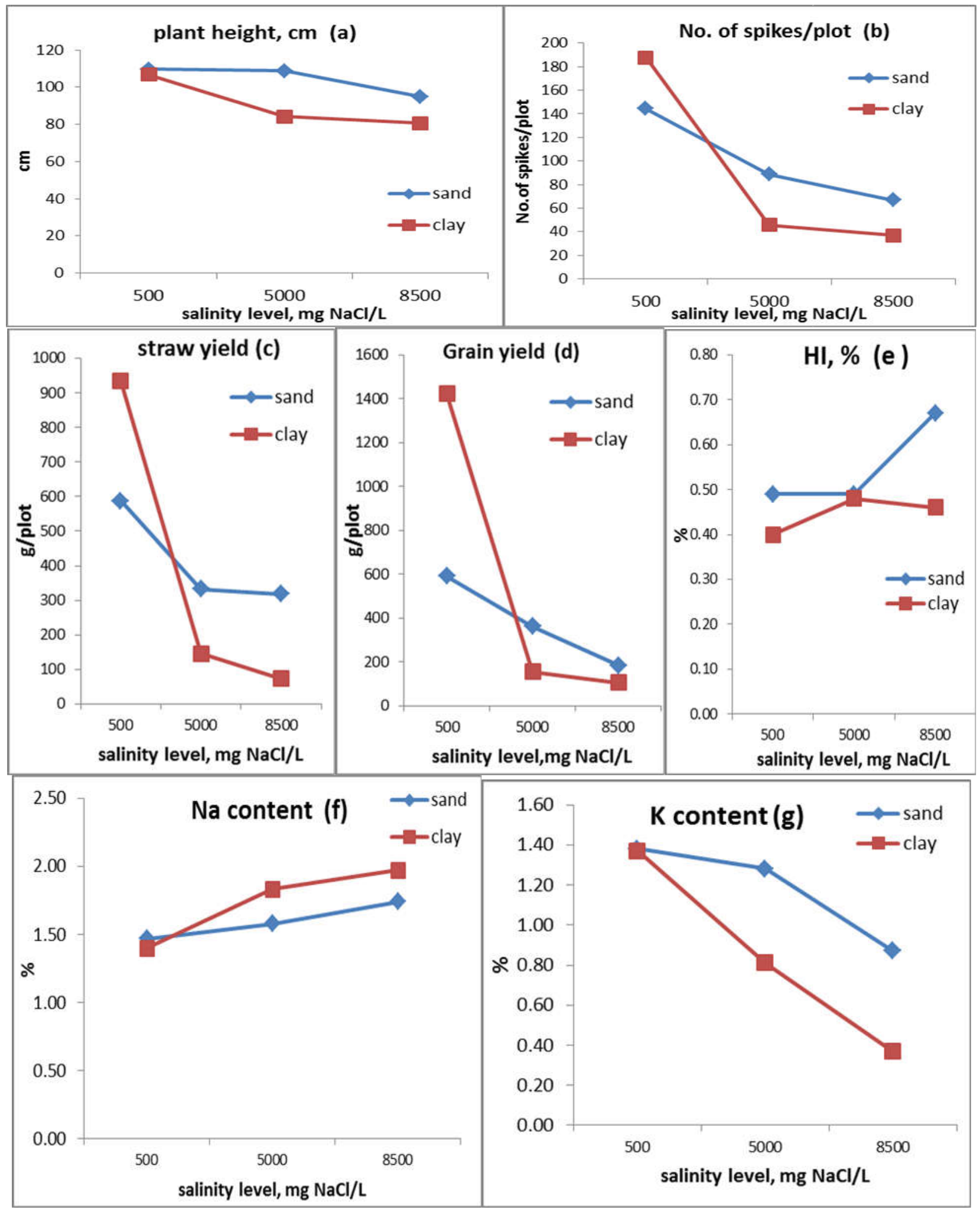

Fig. 4. Plant height (a), number of spikes (b), straw and grain yield (c \& d), harvest index (HI) (e ), leaf Na and K content (f \& g) of wheat as influenced by the interaction between salinity level and soil types. 
Table 3. Growth indices, yield components and leaf chemical composition of wheat plants in relation to the interaction effects of salinity and soaking period

\begin{tabular}{|c|c|c|c|c|c|}
\hline \multirow[t]{2}{*}{ treatments } & \multirow{2}{*}{$\begin{array}{l}\text { salinity level, } \\
\text { mg NaCl / L }\end{array}$} & \multicolumn{3}{|c|}{ soaking period, hr } & \multirow{2}{*}{$\begin{array}{l}\text { LSD, } \\
5 \%\end{array}$} \\
\hline & & 0 & 24 & 36 & \\
\hline \multirow{3}{*}{ Plant height, $\mathrm{cm}$} & 500 & 103.7 & 111.8 & 109.1 & \multirow{3}{*}{ n.s } \\
\hline & 5000 & 94.0 & 98.0 & 97.3 & \\
\hline & 8500 & 82.9 & 90.0 & 90.5 & \\
\hline \multirow{3}{*}{ No.of spikes/plot } & 500 & 136.4 & 158.9 & 203.2 & \multirow{3}{*}{16.2} \\
\hline & 5000 & 53.0 & 86.3 & 62.7 & \\
\hline & 8500 & 36.8 & 58.3 & 60.9 & \\
\hline \multirow{3}{*}{ SY, g/plot } & 500 & 792.7 & 928.5 & 1301.6 & \multirow{3}{*}{76.0} \\
\hline & 5000 & 187.1 & 336.9 & 253.5 & \\
\hline & 8500 & 44.1 & 180.4 & 211.8 & \\
\hline \multirow{3}{*}{ GY, g/plot } & 500 & 581.7 & 771.4 & 928.9 & \multirow{3}{*}{62.0} \\
\hline & 5000 & 203.4 & 271.6 & 243.1 & \\
\hline & 8500 & 171.7 & 210.6 & 203.3 & \\
\hline \multirow{3}{*}{ HI, \% } & 500 & 0.42 & 0.47 & 0.45 & \multirow{3}{*}{0.07} \\
\hline & 5000 & 0.51 & 0.46 & 0.50 & \\
\hline & 8500 & 0.74 & 0.51 & 0.45 & \\
\hline \multirow{3}{*}{$\begin{array}{l}\text { leaf } \mathrm{Na} \text { content, } \\
\%\end{array}$} & 500 & 1.33 & 1.58 & 1.40 & \multirow{3}{*}{0.22} \\
\hline & 5000 & 1.65 & 1.65 & 1.82 & \\
\hline & 8500 & 2.02 & 1.90 & 1.65 & \\
\hline \multirow{3}{*}{$\begin{array}{l}\text { leaf } \mathrm{K} \text { content, } \\
\%\end{array}$} & 500 & 1.20 & 1.70 & 1.23 & \multirow{3}{*}{0.21} \\
\hline & 5000 & 1.34 & 0.69 & 1.11 & \\
\hline & 8500 & 0.66 & 0.64 & 1.10 & \\
\hline
\end{tabular}

As for the soaking period prolonged to $36 \mathrm{~h}$., the number of spikes/plot was significantly dropped only at $5000 \mathrm{mg} \mathrm{NaCl} / \mathrm{L}$ salinity treatment. At the highest saline irrigation water treatment, the variation was not remarkable. The data of the 2-way interaction proved that soaking treatment in $\mathrm{H}_{2} \mathrm{O}_{2}$ for $24 \mathrm{~h}$ was primitive to induce better results on the number of spikes/plot of wheat plants irrigated with water of $5000 \mathrm{mg} \mathrm{NaCl} / \mathrm{L}$.

As for the number of spike/plot records, similar trends were noted on straw and grain yields. The data in table 3 indicating that at moderate salt stress exposure, promising results could be realized when the wheat seeds are soaked in $\mathrm{H}_{2} \mathrm{O}_{2}$ for $24 \mathrm{~h}$.

Plants subjected to saline irrigation water acted to increase their $\mathrm{Na}$ content in leaves as the salinity level increased at each period of $\mathrm{H}_{2} \mathrm{O}_{2}$-pretreated seeds (Table 3). At any given treatment of seed soaking period, the differences in leaf $\mathrm{Na}$ content were significant at $\mathrm{P} \leq 0.05$. At the low salinity level $(5000 \mathrm{mg}$ $\mathrm{NaCl} / \mathrm{L}$ ), the differences between leaves $\mathrm{Na}$ content along the all soaking treatment were statistically insignificant. This trend was also pronounced at the control treatment (irrigation water of $500 \mathrm{mg} \mathrm{NaCl} / \mathrm{L}$ ) whereas the calculated deviation between 24 and 36 soaking periods was not significant. Similarly, at the highest water salinity level $(8500 \mathrm{mg} \mathrm{NaCl} / \mathrm{L})$, the difference between non soaked seeds and $24 \mathrm{~h}$ presoaked seeds was not significant (Table 3).

Nonetheless, salinity stress reduced leaf $\mathrm{K}$ content as the salinity level increased at each period of $\mathrm{H}_{2} \mathrm{O}_{2}$ pretreated seeds (Table 3). At any given soaking seeds period, the differences in leaf $\mathrm{K}$ content were significant at $\mathrm{P} \leq 0.05$. At the highest salinity level $(8500 \mathrm{mg}$ $\mathrm{NaCl} / \mathrm{L}$ ) the differences in leaf $\mathrm{K}$ content between the non-soaked treatment and $24 \mathrm{~h}$ soaking period was not significant and soaked seeds for $36 \mathrm{~h}$ caused significant increase in leaf $\mathrm{K}$ content as compared with the other traits (Table 3 ).

Wahid et al. (2007) reported that exogenous $\mathrm{H}_{2} \mathrm{O}_{2}$ improved salinity tolerance in Triticum aestivum when seeds were soaked in $\mathrm{H}_{2} \mathrm{O}_{2}(1-120 \mu \mathrm{M}, 8 \mathrm{~h})$ and subsequently grown in saline conditions $(150 \mathrm{mM} \mathrm{NaCl})$. $\mathrm{H}_{2} \mathrm{O}_{2}$ levels in the seedlings, arising from $\mathrm{H}_{2} \mathrm{O}_{2}$ - treated seeds, 


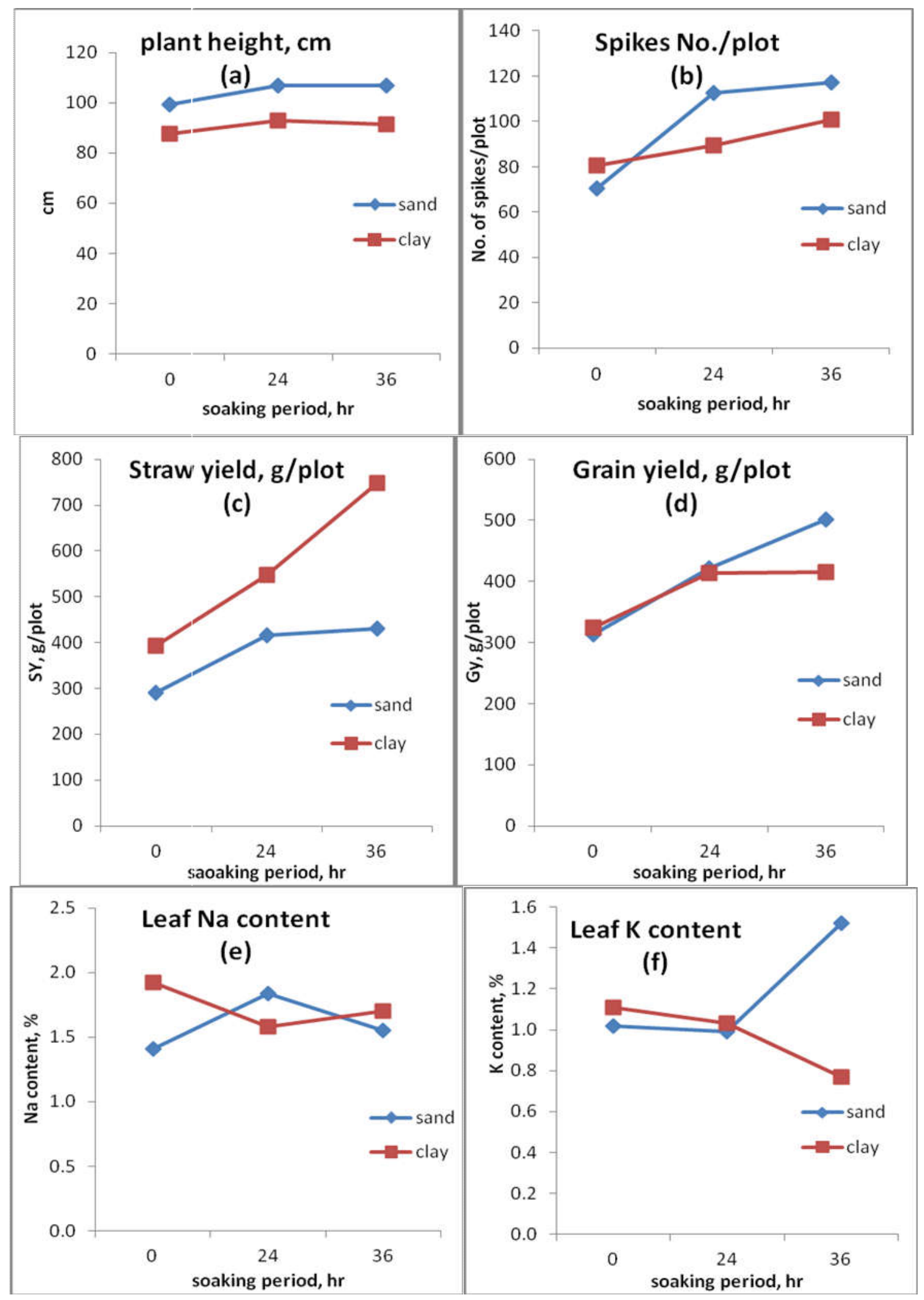

Fig. 5. Plant height (a), number of spikes (b), straw and grain yield (c \& d), leaf $N a$ and $K$ content (e \& f) of wheat as influenced by the interaction between soil types and soaking period 
were markedly lower when grown under saline conditions than control seedlings from non-treated seeds with $\mathrm{H}_{2} \mathrm{O}_{2}$, and also exhibited better photosynthetic capacity. These results suggest that seedlings from $\mathrm{H}_{2} \mathrm{O}_{2}$-treated seeds had more effective antioxidant systems than that found in untreated controls. Moreover, the $\mathrm{H}_{2} \mathrm{O}_{2}$ treatment appeared to improve leaf water relations, stimulating turgor pressure, and improved the $\mathrm{K}^{+}: \mathrm{Na}^{+}$ratio of salt stressed seedlings. $\mathrm{H}_{2} \mathrm{O}_{2}$ treatment also enhanced membrane properties, with greatly reduced relative membrane permeability (RMP) and lower ion leakage (Hossain et al., 2015). The above findings indicate that $\mathrm{H}_{2} \mathrm{O}_{2}$ metabolism might be important for the induction of salt tolerance. Li et al. (2011) reported that cellular defense antioxidant mechanisms were enhanced by the exogenous application of $\mathrm{H}_{2} \mathrm{O}_{2}$ in wheat seedlings under salt stress. Ashfaque et al. (2014) conducted an experiment to study the role of $\mathrm{H}_{2} \mathrm{O}_{2}$ in mitigating salt stress in wheat (Triticum aestivum L.) plants. Treatment of plants with $\mathrm{H}_{2} \mathrm{O}_{2}$ positively influenced plant growth under saline and non-saline conditions. The application of 50 or 100 $\mu \mathrm{M} \mathrm{H}_{2} \mathrm{O}_{2}$ reduced the severity of salt stress, with reductions in both $\mathrm{Na}^{+}$and $\mathrm{Cl}^{-}$ion levels and an increase in proline content and in $\mathrm{N}$ assimilation.

\subsection{Soil type - soaking period interaction}

Irrespective to the effect of salinity, soaking seeds in $\mathrm{H}_{2} \mathrm{O}_{2}$ for $24 \mathrm{~h}$ or $36 \mathrm{~h}$ exhibited marked increments on plant growth parameters and yield components of wheat grown under the two different types of soil (Fig.5).

At any given soaking period, marked differences in plant height were clearly manifested between the two soil types, accomplished with greater performance in sandy than in clay soils (Fig. 5a). Because of the similar interaction trend, all the differences in plant height between the concerned soil types were not significant at $\mathrm{P} \leq 0.05$

In sandy soil, the number of developed spikes / plot was successively enhanced, along the soaking intervals of seeds in $\mathrm{H}_{2} \mathrm{O}_{2}$, but the rate of response was relatively lower in clay soil than the counter clay soil. The different reaction between the selected soil types is presented in figure $5 \mathrm{~b}$, indicating marked deviations in this criteria, particularly at the $24 \mathrm{~h}$ soaking seed interval. The LSD comparisons showed that the difference in tillering index between the selected soils of the control treatment (non-soaked seeds) was not significant at $\mathrm{P} \leq 0.05$. in contrast to the previous results, the data reported on SY data and presented in Fig. 5c revealed that wheat cultivated in clay soil exhibited greater dry matter yield along the entire soaking period than the sandy-textured soil. the LSD comparisons between the 2 different soil types revealed that wider deviations were existed, especially, at the $36 \mathrm{~h}$ presoaking period, (Fig. 5c) The results detected on GY clarified that there is no significant difference between wheat grain yields that cultivated in the two soil types at control treatment and soaking seeds for $24 \mathrm{hr}$ in $\mathrm{H}_{2} \mathrm{O}_{2}$ solution (Fig. 5d). The data also showed that wheat cultivated in sand soil gives the highest significant grain yield when seeds soaked for $36 \mathrm{hr}$ as compared with wheat cultivated in clay soil (Fig.5d).

The leaf mineral composition showed that $\mathrm{Na}$ content was relatively increased in plants grown in clay soil at zero and $36 \mathrm{~h}$ soaking period as compared with sand soil. the LSD comparisons proved that such differences were only significant at $\mathrm{P} \leq 0.05$ for the control treatment when seeds soaked for $24 \mathrm{~h}$ in $\mathrm{H}_{2} \mathrm{O}_{2}$ solution, leaf $\mathrm{Na}$ content in plants cultivated in clay soil exhibited significant decrease as compared with sand one (Fig.5e).

Unlike the previous outlined trend on leaf $\mathrm{Na}$ content, the results documented on the effect of soaking period treatment on $\mathrm{K}$ content were quite different, revealing that plants cultivated in both soils exerted similar reaction with respect to their potentials supply at 0 and 24 h-soaking periods and the differences between the two types of soil were not significant. Subsequently, increasing soaking time to $36 \mathrm{~h}$ imposed significant increase in $\mathrm{K}$ content in plants grown in the sandy than in clay soils (Fig. 5f)

From the above results we can concluded that, seed priming with $\mathrm{H}_{2} \mathrm{O}_{2}$ for $36 \mathrm{~h}$ improve wheat performance, grain yield and leaf $\mathrm{K}$ content in plants grown in sandy soil as compared with the other treatments or the other soil.

\section{DISCUSSION}

Priming is potentially an important mechanism of induced resistance in plants against biotic stresses (Beckers and Conrath, 2007; Borges et al., 2014). Recent studies have shown that priming can also modulate abiotic stress tolerance (Filippou et al., 2012; Hossain and Fujita, 2013; Mostofa and Fujita, 2013; Borges et al., 2014; Wang et al., 2014a). Mounting evidence suggests that the initial exposure to chemical priming agents (such as $\mathrm{H}_{2} \mathrm{O}_{2}, \mathrm{ABA}, \mathrm{NO}, \mathrm{SA}$ etc.) renders plants more tolerant to abiotic stresses (Wang et al.,2010a; Hasanuzzaman et al.,2011a; Sathiyaraj et al.,2014). A number of studies on plants have demonstrated that the pre-treatment with an appropriate level of $\mathrm{H}_{2} \mathrm{O}_{2}$ can enhance abiotic stress tolerance through the modulation of multiple physiological processes, such as photosynthesis, and by modulating multiple stress-responsive pathways (Hossain and Fujita, 
2013; Wang et al., 2014a). The above findings and our results demonstrate that $\mathrm{H}_{2} \mathrm{O}_{2}$ priming can induce tolerance to salinity in plants by modulating physiological and metabolic processes such as photosynthesis, proline accumulation and ROS detoxification, and that this ultimately leads to better growth and development. Moreover, priming treatments are being used to shorten the time between planting and emergence and protect seeds from biotic and abiotic factors during critical phase of seedling establishment which leads to uniform stands and improve yield (Afzal et al., 2011).

\section{REFERENCES}

Afzal I, Basra SMA, Ahmad N. 2011. Hormonal priming induces salt tolerance in wheat through enhanced antioxidant defense system. Cereal Res Comm 39:334342.

Ahmed, Z., M. A. Sheikh; A. Hameed and S.ud Din .2012.Investigation of Antioxidant Enzymes and Biochemical Changes in the Wheat Seeds (Freed) Induced by Different Pre-Sowing Treatments. World App. Sci. J. vol: 18 (1): 31-36

Amin, A.A., H.M. Rashad and A.E. Gharib, 2008. Changes in morphological, physiological and reproductive characters of wheat plants as affected by foliar application with salicylic acid and ascorbic acid. Australian Journal of Basic and Applied Sciences, 2(2): 252-261.

Asada, K. 1999. The water-water cycle in chloroplasts: scavenging of active oxygen and dissipation of excess photons. Annu. Rev. Plant Physiol. Plant Mol. Biol. 50:601-639.

Ashfaque, F., Khan, M.I.R., and Khan, N.A. 2014. Exogenously applied $\mathrm{H}_{2} \mathrm{O}_{2}$ promotes proline accumulation, water relations, photosynthetic efficiency and growth of wheat (Triticum aestivum L.) under salt stress. Annu. Res. Rev. Biol. 4, 105-120.

Azevedo Neto, A.D., J.T. Prisco, J. Enéas-Filho, J.R. Medeiros and E. Gomes-Filho 2005. Hydrogen peroxide pre-treatment induces salt-stress acclimation in maize plants. J. Plant Physiol. 162:1114-1122.

Azevedo-Neto, D., J. Prisco, J. Eneas, C. De Abreu and E. Gomes .2006. Effect of salt stress on antioxidative enzymes and lipid peroxidation in leaves and roots of salttolerant and salt sensitive maize varieties. Environ. Exp. Bot. 56:87-94.

Bauder, J. W. and T.A. Brock .2001. "Irrigation water quality, soil amendment, and crop effects on sodium leaching." Arid Land Res.\& Manage. 15:101-113.

Bauder, J.W. and T.A. Brock .1992. "Crops species, amendment, and water quality effects on selected soil physical properties." Soil Sci. Soc. of Amer. J. 56: 12921298.

Beckers, G.J.M., and, U. Conrath. 2007. Priming for stress resistance: from the lab to the field. Curr. Opin. Plant Biol. 10, 1-7.
Borges, A. A., D. Jiménez-Arias; M. Expósito-Rodríguez; L. M. Sandalio and J. A. Pérez. 2014. Priming crops against biotic and abiotic stresses: MSB as a tool for studying mechanisms. Front. Plant Sci. 5:642.

Cakmak I, D. Strbac, H. Marschner .1993 Activities of hydrogen peroxide scavenging enzymes in germinating wheat seeds. J. Exp. Bot. 44:127-132.

CoHort software, 1986. CoSTAT user manual version 3.03. Berkeley, CA, USA.

Duncan, D.B. 1965. A Bayesian approach to multiple comparisons. Technometrics, 7:171-222.

Evenhuis and De-Waard 1980. Principles and Practices in Plant Analysis. FAO soils Bull. 38(1):152-163.

FAO. 2005. Global network on integrated soil management for sustainable use of salt-affected soils. http://www.fao.org/ag/AGL/agll/spush.

Filippou, P., G. Tanou, ,A. Molassiotis and V. Fotopoulos. 2012."Plant acclimation to environmental stress using priming agents," in: Plant Acclimationto Environmental Stress, eds N. Tuteja and S. S. Gill (Berlin,NY: Springer Science \& Business Media),1-28.

Gondim, F. A., E. Gomes-Filho, C. F. Lacerda; J. T. Prisco, A. D. Azevedo Neto and E. C. Marques .2010. Pretreatment with $\mathrm{H}_{2} \mathrm{O}_{2}$ in maize seeds: effects on germination and seedling acclimation to salt stress. Braz. J. Plant Physiol., 22(2): 103-112.

Gondim, F.A., E. Gomes-Filho; J. H. Costa, N. L. M. Alencar and J. T. Priso.2012. Catalase plays a key role in salt stress acclimation induced by hydrogen peroxide pretreatment in maize. J. Plant Physiol. Biochem. 56, 62-71.

Gong M., B. Chen, Z. G. Li and L.H. Guo.2001.Heat-shockinduced cross adaptation to heat, chilling, drought and salt in maize seedlings and involvement of $\mathrm{H}_{2} \mathrm{O}_{2}$. J. Plant Phyisol. 158:1125-1130.

Grattan, S.R. and J.D. Oster. 2003. Use and reuse of salinesodic waters for irrigation of crops. In: S.S. Goyal, S.K. Sharma and D.W. Rains (eds.), Crop Production in Saline Environments: Global and Integrative Perspectives. Haworth Press, New York. pp 131-162.

Hameed, A., S. Farooq, N. Iqbal, R. Arshad.2004. Influence of exogenous application of hydrogen peroxide on root and seedling growth on wheat (Triticum aestivum L.). Int. J. Agric. Biol. 6(2):366-369

Hasanuzzaman, M., M. A. Hossain and M. Fujita 2011a. Nitric oxide modulates antioxidant defense and the methylglyoxalde toxification system and reduces salinityinduced damage of wheat seedlings. Plant Biotechnol. Rep. 5, 353-365.

Hossain, M. A., S. Bhattacharje, S-M. Armin, P. Qian; W. Xin, H-Y Li, D. J. Burritt; M. Fujita and L-SP. Tran. 2015. Hydrogen peroxide priming modulates abiotic oxidative stress tolerance: insights from ROS detoxification and scavenging. Front. Plant Sci. 6: 420.

Hossain, M.A., and M. Fujita. 2013. Hydrogen peroxide priming stimulates drought tolerance in mustard (Brassica juncea L.). Plant Gene Trait. 4, 109-123. 
Li, J. T., Z.B. Qiu, X. W. Zhang and L. S. Wang. 2011. Exogenous hydrogen peroxide can enhance tolerance of wheat seedlings to salt stress. Acta Physiol. Plant. 33, $835-842$.

Mahajan S., N. Tuteja. 2005. Cold, salinity and drought stresses: an overview. Arch Biochemistry and Biophysics.444: 139-158

Mostofa,M.G., and M. Fujita, 2013. Salicylic acid alleviates copper toxicity in rice (Oryz asativa L.) seedlings by upregulating anti oxidative and glyoxalase systems. Ecotoxicology 22, 959-973.

Page, A.L.; R.H. Miller and D.R. Keeney (eds) 1982. Methods of Soil Analysis. Part 2. American Society of Agronomy, Madison, W.I.

Parida, A.K. and A.B. Das .2005. Salt tolerance and salinity effects on plants: a review. Ecotoxicol. Environ. Safety, 60: 324-349.

Sathiyaraj, G., S. Srinivasan, Y. J. Kim, O. R. Lee; S. D. R. Balusamy; A. Khorolaragchaa, et al.2014. Acclimation of hydrogen peroxide enhances salt tolerance by activating defense-related proteins in Panax ginseng CA. Meyer. Mol. Biol. Rep. 41, 3761-3771.

Silva, C., V. Martinez and M. Carvajal. 2008. Osmotic versus toxic effects of $\mathrm{NaCl}$ on pepper plants. Biol. Plantarum, 52(1): 72-79.
Ślesak, I, M. Libik, B. Karpinska, S. Karpinski and Z. Miszalski. 2007. The role of hydrogen peroxide in regulation of plant metabolism and cellular signalling in response to environmental stresses. Acta Biochim. Pol. 54:39-50.

Uchida, A, A. T. Jagendorf, T. Hibino and T. Takabe. 2002. Effects of hydrogen peroxide and nitric oxide on both salt and heat stress tolerance in rice. Plant Sci. 163:515-23.

Wahid, A., M. Perveen, S, Gelani and S. M. A. Basr. 2007. Pretreatment of seed with $\mathrm{H}_{2} \mathrm{O}_{2}$ improves salt tolerance of wheat seedlings by alleviation of oxidative damage and expression of stress proteins. J. Plant Physiol. 164, 283294.

Wan, X.Y. and J. Y. Liu. 2008. Comparative proteomics analysis reveals an intimate protein network provoked by hydrogen peroxide stress in rice seedling leaves. Mol Cell Proteomics 7:1469-1488

Wang,Y., J. Li, J. Wan and Z. Li. 2010a. Exogenous $\mathrm{H}_{2} \mathrm{O}_{2}$ improves the chilling tolerance of manila grass and mascarene grass by activating the antioxidative system. Plant Growth Regul. 61, 195-204.

Wang,Y., J. Zhang, J. L. Li and X. R. Ma. 2014a. Exogenous hydrogen peroxide enhanced the thermo tolerance of Festuca arundinacea and Lolium perenne by increasing the antioxidative capacity. Acta Physiol. Plant 36, 29152924. 


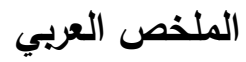

\section{أستجابة نباتات القمح لنقع الحبوب في محلول فوق اكسيد الهيدرجين تحت ظروف الاجهاد الملحي}

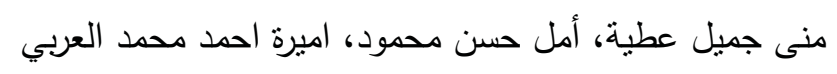

اظهرت النتائج حدوث انخفاض معنوي في نمو النبات

والمحصول مع زيادة الاجهاد الملحي لماء الري مع اختلاف معدل الانخفاض للصفات المدروسـة. وكان التاثير الاكثر

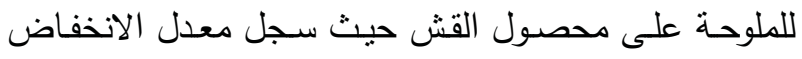

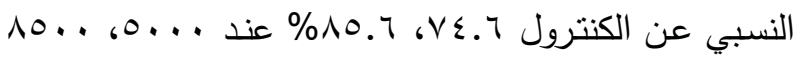
مجم NaCl / لتر على التوالي. ولقد ساهمت معاملة الحبوب بالنقع لمدة بساساعة في محلول

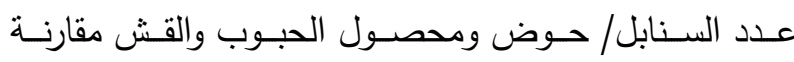

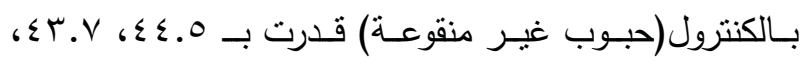

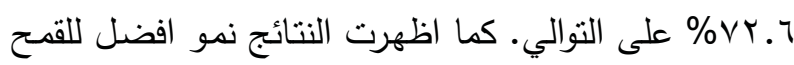
النامي في الارض الرملية مقارنة بالارض الطينية. كما تميز

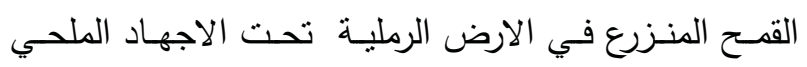

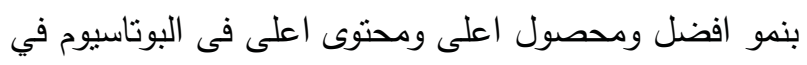

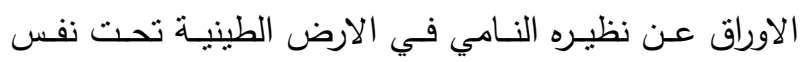

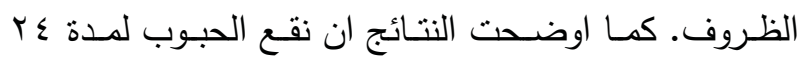
ساعة في محلول $\mathrm{H}_{2} \mathrm{O}_{2}$

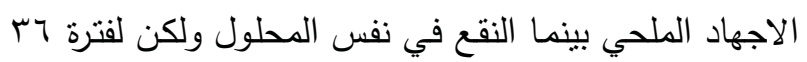

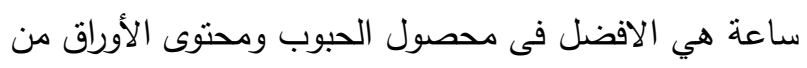

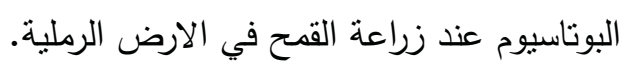

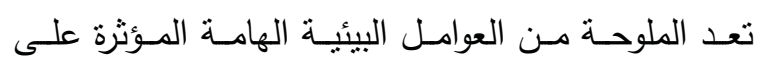

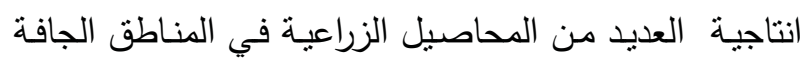

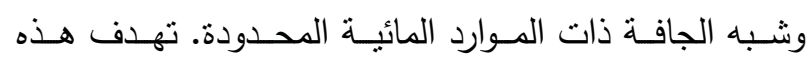
الدراسـة لاختبار مساهمة نقع الحبوب في محلول

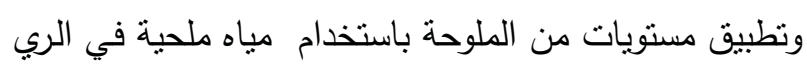

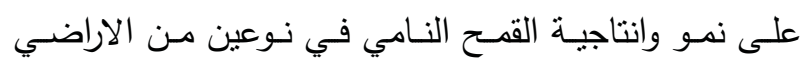
مختلفة القوام. ولتحقيق هذا الهدف تم تصميم تجربة عاملية

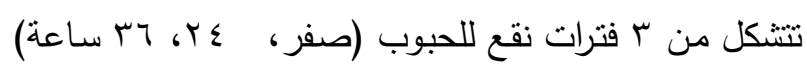

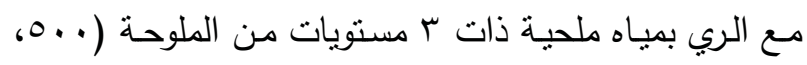

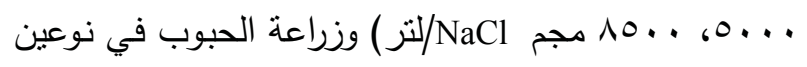

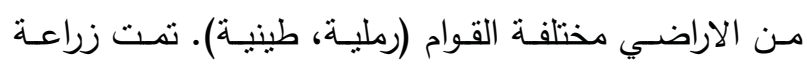

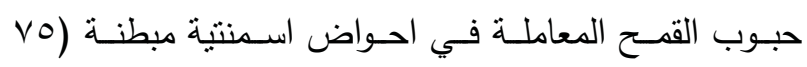
x x (سم) وتطبيق ما سبق ذكره من معاملات حتى النضـج.

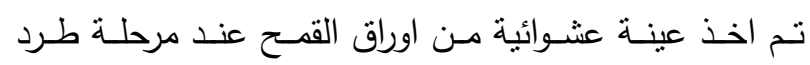

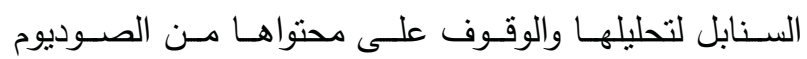

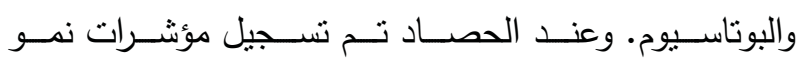
النباتات(طول النبات، عدد السنابل/ حوض) وايضا مكونات المحصول (القش والحبوب). 